\title{
A Symbolic Interaction Analysis of Waria (Transgender Women) in Makassar - Eastern Indonesia
}

\section{Kurniati Abidin 1 (D), and Yusuf Djabbar ${ }^{2}$}

${ }^{1}$ Department of Islamic Communication and Broadcasting, Faculty of Usuluddin and Dawah, State Islamic Institute of Bone, 92733 Bone, South Sulawesi, Indonesia.

2 Department of Constitutional Law (Siyasah Syar'iyyah), Faculty of Sharia and Islamic Law, State Islamic Institute of Bone, 92733 Bone, South Sulawesi, Indonesia.

* Corresponding Author: kurniatiarifabidin@gmail.com

\section{ARTICLE INFO}

\section{Publication Info: \\ Research Article}

How to cite:

Abidin, K., E Djabbar, Y. (2019).

A Symbolic Interaction Analysis of Waria (Transgender Women) in Makassar - Eastern Indonesia. Society, 7(2), 195-212.

DOI : 10.33019/society.v7i2.113

Copyright () 2019. Owned by Author(s), published by Society

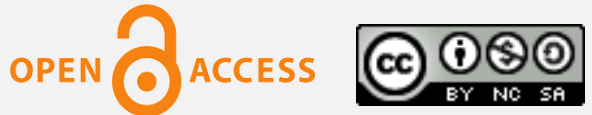

This is an open access article.

License: Attribution-

NonCommercial-ShareAlike (CC BY-NC-SA)

Received: November 5, 2019; Accepted: December 26, 2019; Published: December 31, 2019;

\begin{abstract}
Transgender women (in Indonesia known as Waria) still experience social stigma and exclusion in society. This phenomenon is interesting to study because it is related to the existence of transgender women in dealing with stigma and social exclusion. This study aims to describe the way transgender women perceive social exclusion and to describe the construction of their knowledge which, despite facing social exclusion, still maintains their existence. This study used a qualitative-phenomenological study method, using a purposive sampling technique. Data collection was done by conducting observations, in-depth interviews, and documentation. Data were analyzed using qualitative descriptive using symbolic interaction theory. The results showed that transgender women perceive the stigma and social exclusion they faced was manifested by planned actions in the form of conditional neglect and delay in introducing their existence. They respond to social situations they face with adaptive and not frontal. Transgender women's knowledge construction to maintain their existence is passed through four stages, namely impulse, perception, manipulation, and completion.
\end{abstract}




\section{Introduction}

Humans are born in two sex forms, male and female. Over time, the changes occur; some men change their appearance or gender into women and feel themselves as women, also, not a few women change their appearance and behavior like men.

The phenomenon of transgender persons has been around for a long time and they are considered deviant people. Transgender women (in Indonesia known as Waria), is a variant of the transgender phenomenon which is classified as a transgender type of MtF (Male to Female). By birth as a male but there is a desire to be accepted as a woman by society.

In Indonesia, the number of waria populations is not known with certainty. The Ministry of Health Republic of Indonesia stated that there was a significant increase in the number of transgender women between 2002 and 2009, but there was no increase between 2009 and 2012. The population is not certain but referring to data on populations prone to being affected by HIV, the number of waria is estimated at 597 thousand people, while men are included in the bisexual category reached more than 1 million people (Kementerian Kesehatan Republik Indonesia, 2014).

Although gradually the people have begun to understand and accept the existence of transgender women, they still face stigma and social exclusion. Pierson (2002: 15) stated that social exclusion is a process that blocks or inhibits individuals and families, groups and villages from the resources needed to participate in social, economic, and political activities in society as a whole. The community accepts waria`s participation very specifically which is the acceptance of special functions that are considered to be their expertise such as work in a beauty salon and bridal makeup.

The social exclusion will certainly be followed by actions that harm their interests. In the book "Harsh Realities: The Experiences of Transgender Youth in Our Nation's Schools", Greytak et al., (2009: xi) revealed the facts about the treatment of transgender students in schools in the USA as follows:

a. Almost all transgender students had been verbally harassed (e.g., called names or threatened) in the past year at school because of their sexual orientation $(89 \%)$ and their gender expression (87\%);

b. Over half of all transgender students had been physically harassed (e.g., pushed or shoved) in school in the past year because of their sexual orientation (55\%) and their gender expression (53\%);

c. Many transgender students had been physically assaulted (e.g., punched, kicked, or injured with a weapon) in school in the past year because of their sexual orientation (28\%) and their gender expression $(26 \%)$;

d. Although LGBT students overall reported high levels of harassment and assault in school, transgender students experienced even higher levels than non-transgender students;

The unfair treatment of transgender people is referred to as a general phenomenon that is relatively the same in every country. The community's treatment certainly does not symbolize a humanistic approach.

Culturally, people in South Sulawesi, Indonesia, (Eastern Indonesia), recognize a transgender variant called calabai and another is bissu. There are five gender variants in the culture of South Sulawesi, namely men-calabai-bissu-balaki-women. Calabai is similar to the type of $\mathrm{MtF}$ (Male to Female) and balaki is similar to the type of FtM (Female to Male), while bissu cannot be considered as transgender women because they do not wear clothes from any gender group but wear after certain and separate for their group.

Copyright (C 2019. Owned by Author(s), published by Society. This is an open access article under CC-BY-NC-SA license.

https://doi.org/10.33019/society.v7i2.113

196 
The biggest challenges of their existence in society are on people's negative perceptions about themselves. Stigma both on culture and religion is at the root of a negative perspective on transgender women. As citizens, they also have the same rights in the public sphere. However, due to their massive social exclusion, their rights as citizens are hindered. The social exclusion phenomenon is more or less affecting the transgender women which in this study took place in Makassar, South Sulawesi, Indonesia.

The community reactions more or less influenced how the transgender women perceive themselves. The others represented by people bring transgender women to map self-concepts which are then used in interacting in the community. This study, using the perspective of symbolic interaction, seeks to map descriptions of the way transgender women perceive themselves and the role in society, especially how they respond to the social stigma and exclusion they face.

The social exclusion of transgender women provides their perspectives in understanding their existence. The way they understand themselves and their robustness to maintain the existence of their citizenship certainly present problems for them and their community. Therefore, this study aims to describe the way a waria percieves the marginalization and to describe the construction of transgender knowledge which despite facing social exclusion still maintains their existence.

\section{Literature Review}

\section{A. Transgender Concepts and Social Exclusion on Waria}

Transgender is a term that refers to behavior changes in certain sexes that lead to other sexual behaviors. Technically, transgender women types are MtF (Male to Female) and FtM (Female to Male). Waria is in the type of MtF (Male to Female). The term transgender was coined in the late 1980s by men who did not find the label waria adequate to describe their desire to live as women (Carroll et al., 2002: 131).

Physically, a waria is a man by birth but certain mental conditions or experiences make them transformed to live as women. Gesture and femininity are one of the main signs of womanhood. At a certain level, they take extreme measures by changing their genitals. After all, the condition has been distinguished in two key terms; sex and gender.

Benjamin (1999: 6) separates these two terms, sex is more applicable associated with things of sexuality, libido or sexual activities. While gender is the nonsexuality side of sex. Based on the level of expression, gender is "located above" and sex is below the belt. Although the terms are often used interchangeably, sex and gender must be used separately.

Benjamin's statement implicated for two types of waria; waria at the gender level by only changing the gestures and behavior of men to women, and another is not only changing gender but do medical surgery to replace their genital. The last type will also experience changes in sexual activity like women but pregnant.

Being a waria does not change themselves but also changes social relationships that have been happening. Community treats them that allows the waria to experience a lot of depression (Budge et al., 2013: 545)

The studies of anxiety levels and depression in perspectives of sociology occur due to social processes between the waria and the community. A study conducted by Budge et al., (2013) foun $d$ that distress varies based on several factors, including the individual's transition process, the coping mechanism used, and the level of social support. Budge et al., explicitly mentioned the existence of sociological determinants that caused social exclusion in transgender women. 
The main problem of social exclusion in transgender women is behavior irregularities that are considered not following social norms. Social exclusion causes people's acceptance to be at their lowest point. The physical transformation of transgender men is directly proportional to how the transsexual behaves and the reaction of the people who still consider the transformation contrary to social norms. According to Ruhghea et al., (2014: 12), transgender women internalize into the brain about sex that will determine attitudes and behaviors in their social life.

Action and reaction are general laws of social reality. Actions that give rise to behaviors that are considered contrary to the norm automatically meet negative reactions from the local community. From time to time in many places, transgender men tend to get into a conflict which results in conflicts with both family and society in general.

The process of development of a waria (transgender woman) at some level managed to adapt to their environment. Succeeded through psychological difficulties and succeeded in achieving a healthy level of social adjustment and psychological happiness (Pardo, 2008: 2). Nevertheless, it can be ascertained that discrimination, harassment, and fear of rejection become an inseparable part of the growth and development of a person's process of becoming a waria who will face the risk of disruption in growth both psychologically, socially and physically (Grossman \& D'Augelli in Pardo, 2008: 2).

The challenge faced by waria is prevalence. The courage in expressing their behavior is an impossible effort that does not get opposition from the community. At this point, a waria has an experience that will shape his views and the role he plays socially. The variety of responses from the community becomes the raw material for the formation of identity and at the same time fosters a perspective about the transgender self and the challenges it faces. All of this will guide them in adapting to various threats and disturbances.

\section{B. Waria (MtF) Phenomena in Symbolic Interaction Theory}

The symbolic interaction theory focuses on individual analysis, especially the way individuals perceive themselves and their environment. This theory is the antithesis of structural approaches such as structural functionalism theory. This theory was pioneered by G. H. Mead and his student $\mathrm{H}$. Blumer. This theory reveals that the phenomenon of transgender self-concept as a result of interactional processes that are mediated by the configuration of symbols which then affect the social interaction between transgender and the surrounding community.

Symbolic interaction focuses its attention on the actor as the object of discussion. This theory elaborates on the process of interpretation of various symbols carried out by social actors to others. For symbolic interaction theory, the specific actions of actors are centered on the network of good intentions based on an understanding of symbols. The next general action is very possible because of the views are similar to a symbol that occurs due to symbolic interaction between community members. Symbolic capacity pushes an individual to become an object for an individual itself to get the reflective ability of the actions and others toward the individuals themselves (Tsekeris \& Katrivesis, 2008: 7).

During the process of interaction, social actors use symbols that are interpreted reflectively by other social actors to cause diverse reactions. The root of the symbolic interaction process is the theory of social interaction. Social interaction occurs because there are two manifested elements namely social contact and communication. The process of reciprocal relations in the form of communication in this there is an exchange and interpretation of symbols. The theory of

Copyright (C 2019. Owned by Author(s), published by Society. This is an open access article under CC-BY-NC-SA license. 
symbolic interaction has several characteristics expressed by Blumer in Raho (2007: 106) as follows:

1) The ability to think. Individuals in society are not seen as beings who are motivated by actors outside their control to act. Instead, they see humans as being reflective and can, therefore, behave reflectively. Waria or transgender women are social actors who can think that they have independence and the ability to perceive situations outside of themselves.

2) Think and Interact. People have only the ability to think in a general way. This ability must be formed in the process of social interaction. This view brings symbolic interaction to pay attention to one particular form of social interaction, namely socialization. For symbolic interaction, socialization is a dynamic process. In that process, the man not only receives information but the person perceives and adjusts the information according to his needs. Waria or transgender women are social actors who can perceive any community reaction to behavior that is deemed deviant. The results of the transgender interpretation then affect the way transgender women carry out their social interactions.

3) Learning the Meaning of Symbols. In social interaction, people learn symbols and meanings. If people react to signs without thinking then in giving reactions to symbols, people must first think. Signs have meaning in themselves, for example, the movements of an angry dog are a sign that he is angry. While symbols are social objects that are used to represent (take place of) anything that is agreed to represent, for example, the red and white flag is the symbol of the Indonesian nation. Symbols that arise from social interaction between waria and the community. Interpreting meaning is a work step that will affect a transgender's actions towards the community or vice versa.

4) Action and Interaction. The main concern of symbolic interaction is the impact of meaning and symbols in human action and interaction. The impact of social actions in the form of symbols will also have an impact on the social interactions that are formed between waria with the community or vice versa.

5) Make Choices. Because of the ability to understand the meaning and symbols of human beings can make choices about the actions taken. Humans do not need to simply accept the meanings and symbols that are forced upon them. Instead, they can act on their interpretations of the situation. In other words, humans can give new meaning to the situation. The meaning interpreted by a waria from community reactions in the form of symbols will be carefully considered and manifested in the chosen social action according to the social situation faced by the waria.

6) Self. Self is an extremely important concept for symbolic interaction. To understand this concept, we must first understand the idea of looking glass self-developed by Charles Horton Cooley. What is meant by looking glass self by Cooley is that humans can see themselves as themselves see other social objects. The idea of looking glass self can be broken down into three components, namely: first, the self imagines how it will appear to others; secondly, imagine how they would evaluate their appearance; third, how the self develops a certain kind of feeling as a result of the shadow about the person's judgment. Blumer defines self very simply. According to him, self merely means that human beings can be the object of their actions. He does something about himself and directs himself in certain actions. Self allows humans to do something and not just react to stimuli or stimuli that come from outside.

7) Groups and Society. According to Blumer, society is not made of macrostructures. The essence of society must be found in the actor and his actions. Human society must be seen as people acting and community life is seen as part of their actions. Group life is the whole

Copyright (C 2019. Owned by Author(s), published by Society. This is an open access article under CC-BY-NC-SA license. 
action that is taking place. However, society is not made from isolated actions. There are collective actions involving individuals who adjust their actions towards one another. In other words, they influence each other in taking action. Mead called this a social act and Blumer called it a join action.

However, Ritzer \& Smart (2011: 430) argues that the main assumptions of the theory of symbolic interaction are as follows: (a) People are special abilities according to their ability to use symbols, (b) People become human typically through the interaction they have, (c) People involved conscious and self-reflection that actively shapes his behavior, (d) People are purposeful objectives that engage in and fight interactions, (e) Society consists of people who engage in dialogue, (f) To discuss one's social actions, the use of methods that allow seeing the meaning issued by the person with the actions.

As social actors, waria use symbols. This ability is then manifested in the space of social interaction. transgender women are also social actors who have reflective and conscious abilities that are active with these transgender social forms that are formed and are developing. They are actors who have goals that are then opposed to what they face as stigma and social exclusion against transgender women. The society in which transgender members is formed, developed and dynamic because it involves them in the process of symbolic interaction. To understand transgender social actions requires a method that allows seeing the meaning requested by the person with the transgender's actions.

The process of social interaction based on symbolic interaction theory is the social action of social actors. An action directed at other actors with specific aims and objectives. Waria want their existence to be accepted. But the community's reaction allows them getting a reaction that is not as their wishes. The fact that the community is a collection of various relationships and interactions between community members because the social as embedded in relations and interactions society is merely a constellation of individuals who are the actual realities (Simmel in Plummer, 2010: 20)

According to Simmel, the basic of Sociology is a way to comprehensively collaborate on social interactions that are manifested in society. Understanding the self-concept of a waria is an effort to observe in-depth and comprehensively the process of social interaction, especially symbolic interactions between waria and other community members.

Social Actions of Waria are implemented into social spaces that react to various reactions from other community members. Weber in Ritzer (1992: 45) mentioned the five main characteristics of sociological study as follows:

1) Human actions, according to the actor contain subjective meaning. This includes a variety of concrete actions. What waria display in the form of social behavior contains subjective meanings for themselves.

2) Actual and subjective actions thought entirely and are subjective. Waria social action is understood and believed to be the value of subjectivity and is considered true.

3) Actions that include the positive influence of a situation, actions that are intentionally repeated as well as actions in the form of tacit agreement. Social actions that cause positive reactions from community members will always be repeated. In some aspects, the community can accept the social role played by waria in certain segments such as bridal stylists.

4) The action was directed at someone or some individuals. Social actions that contain values believed of waria will be directed to other members of the community. The diversity of

Copyright (C 2019. Owned by Author(s), published by Society. This is an open access article under CC-BY-NC-SA license. https://doi.org/10.33019/society.v7i2.113 
actions and reactions or feedback from other community members will influence the transgender self-concept and subsequent social actions.

5) That action pays attention to the others and is directed at others. Waria social actions are realized and calculated carefully to whom the social actions are directed and what reactions that arise afterward.

\section{Research Methodology}

This study used a qualitative-phenomenological study method. A qualitative study examines social phenomena based on the context that surrounds them. The qualitative study focuses on the in-depth elaboration of an individual's perception of his social world. This means that transgender person perceptions of community behavior are the focus of this study.

The phenomenological method is used to deepen the lived experience by trying to understand deeply the interpretation activities carried out by the informants delaying all forms of presupposition. Kuswarno (2009: 36) stated several characteristics of phenomenological study:

1) Exploring value in human experience and life;

2) The focus of the study is on the whole, not on the parts that make up the whole;

3) The purpose of the study is to find the meaning and nature of experience, not just to search for explanations or to look for measures of reality;

4) Obtain a description of life from a first-person perspective, through formal and informal interviews;

5) The data obtained form the basis for scientific knowledge to understand human behavior;

6) Questions are made reflecting the interests, involvement and personal commitment of the study;

7) Seeing experience and behavior as a unity that can not be separated, both the unity between subjects and objects, as well as between parts and the whole.

This study was conducted in Makassar City, South Sulawesi, Indonesia (Eastern Indonesia), since the waria community in the city is quite large and easy to access. There is also a transgender organization in Makassar as a forum to fight for their rights.

Data collection was done by conducting observations, in-depth interviews with 10 informants and documentation. This study was carried out for 3 months, with earlier observing the transgender community in their boarding house. The technique of taking informants is done by using the purposive technique. Sugiyono (2012: 126) explained the characteristics of a purposive technique that purposive is a technique of taking data sources through certain considerations. The consideration that the study intends is that the informant is the person who is considered most knowledgeable about the focus of the study that the study adopts making it easier to explore the object/social situation under study. As for the characteristics of the informants in this study are men who have changed their appearance to become women (work as transgender women), have been doing it for more than 4 years and until the time of the study were still living as transgender women and living in Makassar City.

After the data collection process was completed, then proceed with conducting data analysis. Kuswarno (2009: 69) explained the stages of qualitative-phenomenological study data analysis as follows:

1) A complete description of events experienced directly by the informants;

2) From the informant's verbal statements then;

3) Perform the steps in section 2 of each informant; 
4) Make a thorough explanation of each meaning and essence of the phenomenon obtained.

5) Horizonalization of data obtained. Such as the activities of completing data from various sources, and other points of view. Including ot her statements that are relevant to the study topic, and other data that have the same value.

6) Make a list of meanings and meaning units.

7) Grouping into groups or certain themes. Try not to have statements that are overlapping and repetitive.

8) Make a description or textural description.

9) Make a structural description.

10) Unifying textural and structural descriptions to produce the meaning and essence of the phenomena constructed.

Then, the data was analyzed using descriptive qualitative by the theory of the symbolic interaction approach.

\section{Results and Discussion}

\section{A. Waria Perception of Their Social Exclusion}

People confirm a common view accepted by the majority that transgender is a kind of life pattern that deviates from what it should be. The community generally has an understanding that being transvestite means to distance you from what is considered normal by the community. In this context transgender women often face stigma and even social exclusion.

Lived experience of transgender women inevitably faces constraints of stigma and social exclusion. Informants in this study also had an experience of stigma and social exclusion. Every informant has experience dealing with social stigma and exclusion. The following are the results of the interview with the first informant:

"Becoming a transpuan (in local language for transgender woman or Waria) there is a phase. In the past time, people always bullied us every day because they underestimated us. We were considered unlucky and all kinds of things. But now, I am grateful. Time changes. Technology and media have been developed and revealed successful transpuan and people regard our potencies so that fewer people are bullying transgender women like us". (Interview, Yl)

The second informant also told the same:

"I have always been close to neighbors, and they already know that I like to hang out with women, so there is no stigma from neighbors, but when I go to the mall, I am often seen by people or also usually laughed at". (Interview, $W d$ )

As in the third informant:

"I am comfortable in other villages (in Manado, North Sulawesi) because I can express myself and identity with long hair looked like a real woman. But in Makassar, I am depressed because I live in a family that does not accept me if I become a transpuan". (Interview, Ay) 
Also fourth informant:

"I often get treated when I go to public places, for example to the mall, but I just ignore it. I used to be yelled at but I just ignored. Moreover, I often get the stigma when I go out in the afternoon and wear a skirt, usually, I get yelled bencong (negative name-calling for transgender women in Indonesia) at but I still don't care". (Interview, Mm)

The lived experience of the informants above confirms the stigma and social exclusion is something inseparable from transvestite life. Varamitha et al., (2014: 106) stated: "Stigma is formed through social cognitive processes, namely cues, stereotypes, prejudices, and discrimination". The components of stigma which include gestures, stereotypes, prejudices, and discrimination can be seen from the information of the informant above. Behavior that is contrary to the norms those are believed and adopted by the majority is a trigger for the emergence of stigma. Goffman in Utami (2018: 190) stated that stigma is a sign or signs that are considered a "disturbance" and therefore is considered less than normal people. Individuals who are stigmatized are considered as dangerous, disabled and somewhat underdeveloped compared to people in general.

Even so, the normative expectations constructed by the community may change. Yl's experience shows a decrease in the escalation of stigma against him. The development of life, especially science and technology also reduces the quantity of stigma against transgender women. At some level, although informants emphasized that stigma was reduced, community normative stigma still considered transgender women abnormal. Transgender women have their way of responding to the stigma that occurs in him. The following is the explanation of the informant:

"Initially when I was bulled, my reaction had to be angry, after a long time I was silent and finally they stopped by themselves and out of 100 people maybe 2 people were still bullying. I am an indifferent person, I think if the more I respond it will clash. I am a hard-working type person, with people stigmatizing and bullying then I have to work, I have to show the results of my works. If they see success, then surely they stop themselves. Therefore, the way I deal with society's stigma is that I must excel, in their minds I should be better than them. I see from them generally from the lower classes who are stigmatizing and bullying. If from among classy and educated people there might not be. So on average they are from marginal people and marginalize us. So with achievement, they will stop themselves". (Interview, Yl)

The second informant said the same:

"There must be a stigma, but for what I do, I just ignore it. If people say that I don't care because we are wrong, but if they poke me then I will be angry". (Interview, Ay)

As in the third informant:

"I feel comfortable being a transpuan because I can express what I want and be comfortable hanging out, dressing like a woman and more confident by becoming a transgender woman. I don't care about people's stigma". (Interview Mm) 
The transactions show that social stigma and exclusion from the community, in general, were responded by conditional neglect. Conditional neglect is characterized by indifference towards ridicule as long as it does not interfere physically. In the perspective of symbolic interaction theory, conditional neglect is a reaction to the symbol of the other party. Forms of verbal and nonverbal cues are symbols that are interpreted by those who undergo social interaction. Every symbol that is born from the process of interaction produces meaning. The meaning is then transmitted through social action to others. Others give reactions that do not always match the wishes of the other party. Mockery, shouting and other treatments are various types of symbols transmitted by people towards transgender women. Symbolic treatment in perception was relatively uniform by transgender women who were informants in this study. All informants produce conditional neglect as a general behavior of the symbolic stimulus of the community.

The center of analysis of symbolic interaction theory is in symbols. Charron in Ahmadi (2008) explained that:

Symbols are social objects in interactions that are used as representatives and communication that are determined by the people who use them. These people give meaning, create and change objects in interactions. These social symbols can be realized in the form of physical objects (invisible objects), words (to represent physical objects, feelings, ideas, and values), and actions (which people do to give meaning in communicating with others). (p. 302)

Conditional neglect in addition to the reaction to the symbolic treatment of the community also symbolizes the symbol which is then directed at the community. Reduced stigma is evidence of symbolic effectiveness in the form of conditional disregarding behavior or actions.

Social situations laden with symbols and one's interpretative activities are the main ingredients of the Theory of Symbolic Interaction. Sobur in Khairan et al., (2016: 4) mentioned the basic premises of the Symbolic Interaction Theory:

1) Individuals respond to a symbolic situation, they respond to the environment including physical objects (objects) and social objects (human behavior) based on the media that these environmental components contain for them. Each informant responds to symbolic situations in the form of stereotypical stimulants that undermine their existence.

2) Meaning is a product of social interaction because that is the meaning does not look at objects, but because humans can color everything not only physical objects, actions, or events (even without the presence of physical objects, actions, or events) but also abstract ideas. The way transgender women respond to stimulants in the form of stigma and social exclusion is the act of meaning born of the informant's social interaction with the community. Informants perceive social situations and respond according to the meaning they construct.

3) The meaning interpreted by an individual can change from time to time in line with changes in the situation found in social interaction. Changes in interpretation are possible because individuals can perform mental processes, namely communicating with themselves. A dynamic social situation also allows the process of meaning to be dynamic. Changes in informant behavior from closed to open are the fruit of the dynamics of meaning based on the dynamics of social situations that differ from time to time. 
Configuring symbol systems in public spaces is a necessary thing in social processes. Every social process reflects the dynamics of symbolic exchange and the complexity of their interpretations. Laksmi (2017) stated that:

Humans use symbols to present their intentions and vice versa. The process of interpreting these symbols to the behavior of the parties involved in social interaction is a product of their interpretation of the world around them. Individuals choose behavior as something worth doing, based on how individuals define the existing situation. Meaning arises because there is an interaction between individuals, which arises from the results of interpretations of the human mind about themselves, and their relationships in society. Understanding of symbols must be understood that symbols are social objects that arise from the results of mutual agreement of the individuals who use them. These individuals give meaning, create, and change objects in interactions. These social symbols can manifest in the form of physical objects, language, and actions. (p. 124)

Transgender women define the situation they face is based on community treatment in the form of perceptions, attitudes and stigmatic actions that underestimate and even undermine their existence. The relatively intense stigma found by the informants caused the informants to respond by ignoring the stigma but with certain limitations. Stigma does not make transgender women or waria an absolute adjustment process. In a sense, changing their existence. The reaction that transgender women show is to do the process of adjustment without having to meet the expectations of the community. The informants remain waria, but differ in strategies especially in dealing with immediate family. The purpose of the adjustment behavior is simply done so as not to make sudden changes that can harm the informant. The adjustment strategy is only done so that the community can accept its existence.

Different strategies often make transgender in the public sphere take the role of adjusting to community expectations. Transgender women who have strategic considerations facing the rigors of social stigma tend not to present themselves as they are in public spaces.

Social interaction occurs or arises because of social objects, symbols, languages, and perspectives that are central to human social life whose importance can be found in human social reality, human social life and individual life. Symbols are nothing but special types of social objects. Language is nothing but a special type of symbol and perspective is a collection of symbols.

Social objects, symbols, languages, and perspectives are constructed by humans so that their social life goes the way they want. Social objects, symbols, languages, and perspectives developed by one group can certainly be different from other groups. The meaning comes from the interpretation of social objects, symbols, languages, and perspectives. Meaning determines the behavior of a person's interactions with others. Social interaction involves communication and meeting/face to face. Informants seek social interaction even though the community still has a negative meaning for them. At this point, the construction of knowledge to reduce the problem of interaction that gives birth to conflict is carried out by the informants.

\section{B. Construction of Waria`s Knowledge to Exist}

The construction of knowledge as something inevitably leads one to interpret something with a specific purpose. In conflictual social situations, the aim of reducing tension is one of the considerations for concocting certain knowledge constructs. The construction of knowledge is something important in sociological analysis. 
Sociology is a branch of science that focuses on human social behavior. The focus of analysis on how humans construct meaning in certain social situations is a unit of micro-sociological analysis.

The phenomenon of transgender life experience involves two processes, namely macro and micro-scale processes. The theory of symbolic interaction focuses more on microanalysis by observing deeply the internal complexity of individuals including the process of constructing knowledge.

The theory of symbolic interaction is a theory that emphasizes the internal dynamics of actors, especially the way an actor constructs the meaning of a symbol. Who we are is very much determined from the interpretations of others, whether we follow the expectations of others or not. Contemplation, ridicule, stereotypes and unpleasant treatments have been part of their lives. Every informant's lived experience cannot be separated from social stigma and exclusion. The informants have a way of constructing symbolic meaning in both verbal and nonverbal forms.

The construction of knowledge is inevitable because each symbol has a certain meaning. Social stigma and exclusion in the eyes of informants are interpreted differently. The following are the statements of the first informant:

"I don't care about the community, I am more focused work earning money. We must be role models of people, motivate people. I am a role model of other transpuan to be their reflection, so I have to do good for many people and have to work hard". (Interview, Yl)

As in the second informant:

"Initially I just "hang out" in Karebosi, looking around and traveling with friends who are also transsexual (in a local language known as transpuan). Indeed, at that time I was invited to a friend. I started to hang out when I was in high school in grade 2 around 1998. I worked so until 20 years and because of the age factor is old so I thought of working in a salon. I want to be called Senior in Herman's Salon, so all my friends at my place of work and fellow transpuan are close. We interact well, even though at Herman's Salon some are not transpuan but we are still close". (Interview, Wd)

Also, the third informant told as follow:

"Although there is a stigma, I still have to work. Initially, I worked as a prostitute. In Makassar, I have always known it up to now. To get my information, by a friend named Ade, I was invited to join the organization. If I enter the organization, if I can get condoms and lubricants so that they are also safety, then I will join the organization in 2001. In 2013 I took a short course from PKBI (a course to improve English language skills). And in 2014, I run a beauty salon, but I continue to be a prostitute at night until this day". (Interview, Ay)

The fourth informant also said that:

"After graduating from high school I worked in a shop for 5 years, but I found it hard to express myself, so I left and worked in a beauty salon. But it turned out that my 
talent wasn't there, although I tried continuously but was unable to work in the salon. Now I have been working for an NGO for 2 years and I am comfortable working here. Our fellow friends support and our fraternity among transpuan is very high". (Interview, Mm)

The statements above show that the way the informant constructs knowledge of the stigma and social exclusion it faces. Knowledge construction is nothing but an act of interpretation of the symbols they receive in the form of stigma and social exclusion from the community. Interpretation influences informant behavior. Behavioral variation is closely related to variations in interpretation. The construction of knowledge is directed at other social actors that provide certain symbolic stimulation.

In the theory of symbolic interaction, humans are perceived as animal symbols. Humans cannot be separated from the act of interpreting symbols. According to Mulyana in Haliemah \& Kertamukti (2017: 496), there are 3 premises of the theory of symbolic interaction namely:

1) Individuals respond to a symbolic situation. They respond to the environment, including physical objects (objects) and social objects (human behavior) based on the meaning that these environmental components contain for them. The response given when facing the situation is not mechanical, nor is it determined by external factors. Their response depends on how they define the situation encountered in social interaction. So it is individuals who are seen as active in determining their environment. The data above shows that the informant was active and responded to the symbolic situation that was stimulated to him. Various interpretations mean that humans are not mechanical. Humans are active, creative and innovative creatures in constructing knowledge of the social situation they face. The knowledge construction process is the way the informant defines the situation of stigma and social exclusion that it faces.

2) Meaning is a product of social interaction, therefore meaning is not inherent in objects, but is negotiated through the use of language. Negotiations are possible because humans can name everything, not just physical objects, actions or events (even without the presence of physical objects, actions or events), but also abstract ideas. The mockery and ridicule faced by informants are symbolic stimulants in the form of verbal language expressions. The main problem is to negotiate the existence of transgender women from rejection to acceptance. The fact of the study shows that the relations of informants with those closest to them tend to change towards proclamation and automatically eliminate stigma on the part of the family meaning changes.

3) The meaning interpreted by an individual can change from time to time, in line with changes in the situation found in social interaction. Changes in interpretation are possible because individuals can perform mental processes, namely communicating with themselves. Humans imagine or plan what they will do. The facts of the study show that there has been a change in meaning, especially from the community towards the existence of transgender people. This indicates the construction of knowledge is very dynamic. Study facts show changes in meaning occur in the closest people and educated people even though their acceptance varies. Changes in meaning occur because of the process of social interaction of informants with their communities. Some informants understand that with achievement, the quantity and intensity of stigma and social exclusion can decrease. Conditional neglect is a behavior that is planned with the aim that the informants do not face excessive reaction from the community.

Copyright (C 2019. Owned by Author(s), published by Society. This is an open access article under CC-BY-NC-SA license. 
Symbolic interaction theory seeks to observe deeply and comprehensively the internal dynamics of transgender women who are informants in this study. The internal dynamics in question are the process of informants constructing their knowledge in response to social situations in which stigma and social exclusion occur. The problematic social situation faced by the informant requires the informant to be adaptive and not frontal. Observing the responses of informants shows a reluctance to escalate conflicts with the community.

Perception to reduce tension with society in the form of knowledge construction that is considered the most effective in reducing social stigma and exclusion. Mead in Tamunu (2018: 11) revealed 4 elements in social interaction, they are:

1) Impulse. The first stage is the impulse (impulse, impulse) which involves "instant sensory stimulation" and the actor's reaction to the stimulus, the need to do something about it. Hunger is a good example of impulse. Hunger may come from the actor's stomach or may be caused by the presence of food in his environment, or the most likely feeling that arises from a combination of the two. Furthermore, a hungry person must find a way to satisfy an existing impulse. Overall from Mead's theory, impulses involve both actors and their environments. social stigma and exclusion are impulses that influence the way of informants' thinking and behavior. The conditional neglect and postponement strategy of introducing its existence is the response of the impulse that comes from the community.

2) Perception. The second stage of action is perception, i.e the actor seeks, and reacts to stimuli associated with impulses, in this case, hunger and various tools or ways to satisfy it. People can feel or understand stimuli through hearing, smelling, tasting, and so on. People not only respond instantaneously to external stimuli but rather think about it, estimate it through mental depictions. People are not only subject to external stimulation; they also actively choose the characteristics of a stimulus and choose among a group of stimuli. That is, a stimulus may have several dimensions, and the actor can select between them. Mead refused to separate the objects he felt. The act of feeling is what makes it an object for someone; perceptions and objects cannot be separated (dialectically related) with one another. Stimulation in the form of stigma and social exclusion will then be perceived by the informant. This study found that informants understood the stimulation as part of discriminating themselves. One of the informants even categorized the aspects of the stigma of the perpetrators of the stigma and understand if the stigmatized perpetrators were ordinary people, but would not understand if the perpetrators were from educated or educated circles.

3) Manipulation. The third stage is manipulation. When the impulse has manifested itself and the object has been felt, the next step is to manipulate the object or take action to please it. For Mead, the manipulation phase is an important temporary pause in the process so that a response is not realized immediately. A hungry human sees a fungus, but before eating it he may take it first and examine it before eating. People may think of past experiences when they ate certain fungi and the consequences that occur after eating the fungus. Checking and studying before eating the fungus becomes experimental when the actor mentally tests hypotheses about what will happen when the fungus is eaten. Conditional neglect and delays in opening existence are part of the way informants manipulate stigmatic stimulants. Informants take time to consider various strategies. There is a pause to consider several options for answering implants that come from the community.

4) Resolution. Based on the above considerations, the actor may decide to eat the fungus or not, and that is the final phase of the action, settlement (consummation) or more generally taking action to satisfy the initial impulse. The settlement phase is the decision making

Copyright (C 2019. Owned by Author(s), published by Society. This is an open access article under CC-BY-NC-SA license.

https://doi.org/10.33019/society.v7i2.113

208 
phase in responding to the impulse that afflicts transgender women. The settlement phase is also the result of all the deliberations directed at responding to the stigmatic impulses of the community. Conditional neglect and delay in opening up are manifestations of the completion phase.

Based on the study facts, the informant developed 4 elements of Mead social interaction above, namely:

1) The impulse stage, marked by the informant's reaction to stimuli in the form of stigma and social exclusion that they face. Impulse is nothing but a portrait of social interaction between informants and their environment.

2) The stage of perception, marked by a post-impulse analysis which is characterized by efforts to find ways that stigma and social exclusion can be reduced and not endanger himself and his group.

3) The manipulation phase is characterized by manipulating social stigma and exclusion by responding to it. Conditional neglect is a form of manipulation by informants based on knowledge construction and is not realized immediately. The way the informant chooses the moment of expressing his existence is a form of manipulation in the form of a delay in the recognition of the existence of his personality. Two methods of manipulation namely conditional neglect and procrastination are something planned by the informant.

4) The completion phase, marked by the actualization of planned actions from the informants to reduce social stigma and exclusion so that their existence can be understood or accepted. The settlement stage is the stage of decision making over several strategic options to respond to the stigmatic impulses coming from the community. The strategy of conditional neglect and delay in opening existence is the final decision that is considered best by the informant.

The general determination of society about sex is reflected in basically binding social norms. Social sanctions will be actual if there are individuals or groups of individuals whose thoughts and actions conflict with the norm. Transvestite thoughts and behavior are considered to be distorted. This became the basis of social stigma and exclusion befalling transgender women. Social norms, from the perspective of symbolic interaction theory, are collections of symbols that have a very significant meaning in influencing someone.

The problem of symbolic interaction which is the basis of transgender social interaction with the community is a form of communication mediated by symbols that have different bases. General social norms about sex are contrary to the understanding of transgender women. Symbolic conflict is reflected in the structure of knowledge about what is good and right or not. This symbolic conflict naturally affects the social cohesion between transgender and society. Low social cohesion is detrimental to transgender who throughout their lives face social stigma and exclusion.

Low social cohesion between community and waria causes them to develop social interaction strategies gradually to be accepted in the community. Some informants in this study were found trying to adjust and delay opening their identities. The unpreparedness to open a conflict front with the community is the basis of the informant's social actions.

Theoretically, Forrest \& Kearns in Nisa \& Juneman (2012: 90) outlined the areas of social cohesion, namely: (1) shared values and a civic culture, (2) social order and social control, (3) social solidarity, (4) social networking and social capital, and (5) attachment and identification in places (place attachment and identity). This understanding is still sociological (as with most

Copyright (C 2019. Owned by Author(s), published by Society. This is an open access article under CC-BY-NC-SA license. 
studies of social cohesion) and forms the basis for objectively measuring social cohesion or cohesiveness. Bollen \& Hoyle (1990) filled the gap of existing literature on social cohesion. According to them, in addition to objective measurements, measurements of individual group members' perceptions of the level of cohesion with the group must also not be ignored because these perceptions affect the behavior of the individual and the behavior of the group as a whole. Their construction is called the perception of social cohesion (perceived cohesion), is subjective psychological.

The problem of social cohesion between transgender and society lies in conflicting social values which ultimately affect other domains. Conflicting values cause social order to be disrupted, especially in transgender groups. Conflicting values also cause social solidarity between waria and society to tend to be low so that social networks are torn and social capital is difficult to maintain between them. Finally, attachment and identification in the place uprooted or uprooted from transgender women. The community is less accepting of their existence in their environment. People tend to think that transgender women are social anomalies or social deviations.

This community prejudice by Etty \& Sri in Arfanda \& Anwar (2015) caused social conflict between transgender women and the community:

Social conflict impacts the social pressures faced by them. Transvestite life must face social pressure that is coercion from the environment that requires their behavior to want to follow the habits that exist in that environment. There are two social pressures faced by transgender women, namely pressure from families who are usually transgender women seen as a disgrace because transgender women is often framed by the prostitution and abnormal sexual behavior, this usually makes them not comfortable in the family environment. The next pressure is from the community due to behavior that deviates from the norm". (p. 96)

The social pressure of transgender women experiencing stigma and social exclusion is a logical consequence that must be faced by transgender as reflected in this study.

\section{Conclusions}

The study of Waria (Transgender women) in perspective of Symbolic Interaction Theory generated a conclusion that a way of waria or transgender women perceive their social exclusion is manifested in planned actions in the form of conditional neglect and delay in introducing their existence. These two actions stem from the perception that a problematic existence should not lead to a large escalation of the conflict. The construction of transgender knowledge to maintain its existence is passed through 4 stages of interaction according to the symbolic interaction theory they are impulse, perception, manipulation, and resolution. Knowledge construction is nothing but an act of informant's perceptions of the social situation in the form of stigma and social exclusion.

\section{Acknowledgement}

The authors would like to thank the Research and Community Service Institute (Indonesian: Lembaga Penelitian dan Pemberdayaan kepada Masyarakat or LP2M), State Islamic Institute of Bone, for funding support and facilities for making this study a success through Interdisciplinary Basic Research Grant Scheme (Indonesian: Hibah Penelitian Dasar Interdisipliner (KP.26/LP2M.9/V/2019/LP2M.9/V/2019)). 


\section{References}

Ahmadi, D. (2008). Interaksi Simbolik: Suatu Pengantar. Mediator: Jurnal Komunikasi, 9(2), $301-$ 316.

Arfanda, F., \& Anwar, S. (2015). Konstruksi Sosial Masyarakat Terhadap Waria. KRITIS: Jurnal Ilmu Sosial dan Ilmu Politik Universitas Hasanuddin, 1(1), 93-102.

Benjamin, H. (1999). The Transsexual Phenomenon. Düsseldorf: Symposium Publishing.

Bollen, K. A., \& Hoyle, R. H. (1990). Perceived cohesion: A conceptual and empirical examination. Social forces, 69(2), 479-504.

Budge, S. L., Adelson, J. L., \& Howard, K. A. (2013). Anxiety and depression in transgender individuals: The roles of transition status, loss, social support, and coping. Journal of consulting and clinical psychology, 81(3), 545-557.

Carroll, L., Gilroy, P. J., \& Ryan, J. (2002). Counseling transgendered, transsexual, and gendervariant clients. Journal of Counseling $\mathcal{E}$ Development, 80(2), 131-139.

Greytak, E. A., Kosciw, J. G., \& Diaz, E. M. (2009). Harsh Realities: The Experiences of Transgender Youth in Our Nation's Schools. Gay, Lesbian and Straight Education Network (GLSEN). 121 West 27th Street Suite 804, New York, NY 10001.

Haliemah, N., \& Kertamukti, R. (2017). Interaksi Simbolis Masyarakat Dalam Memaknai Kesenian Jathilan. Jurnal ASPIKOM, 3(3), 494-507.

Khairan, D., Yusanto, F., \& Primadani, B. (2016). Analisis Konsep Diri Siswi-siswi Penyandang Tunarungu Dan Tunawicara Slb Negeri Cicendo Bandung. eProceedings of Management, $3(2)$.

Kementerian Kesehatan Republik Indonesia. (2014). Estimasi Jumlah Populasi Kunci Terdampak HIV Tahun 2012. Jakarta: Kementerian Kesehatan Republik Indonesia.

Kuswarno, E. (2009). Fenomenologi. Bandung: Widya Padjajaran.

Laksmi, L. (2017). Teori Interaksionisme Simbolik dalam Kajian Ilmu Perpustakaan dan Informasi. Pustabiblia: Journal of Library and Information Science, 1(2), 121-138.

Nisa, A., \& Juneman, J. (2012) Peran Mediasi Persepsi Kohesi Sosial dalam Hubungan Prediktif Persepsi Pemanfaatan Ruang Terbuka Publik terhadap Kesehatan Jiwa. Makara Hubs-Asia, 16(2), 89-100.

Pardo, T. B. (2008). Growing up transgender: Research and theory. Ithaca, New York: Cornell University, Family Life Development Center.

Pierson, J. H. (2002). Tackling Social Exclusion. London and New York: Routledge.

Plummer, K. (2010). Sociology The Basic. The UK: Routledge.

Raho, B. (2007). Teori Sosiologi Modern. Jakarta: Prestasi Pustaka Publisher.

Ritzer, G. (1992), Sosiologi Ilmu Pengetahuan Berparadigma Ganda. Jakarta: Rajawali, Press.

Ritzer, G., \& Smart, B. (2011). Handbook Teori Sosial. Bandung: Nusa Media.

Ruhghea, S., Mirza, M., \& Rachmatan, R. (2014). Studi Kualitatif Kepuasan Hidup Pria Transgender (Waria) di Banda Aceh. Jurnal Psikologi Undip, 13(1), 11-20.

Sugiyono. (2012). Metode Penelitian Kombinasi (Mix Method). Bandung: Alfabeta.

Tamunu, V. R. (2018). Analisis Interaksionisme Simbolik Terhadap Penyimpangan Perilaku Siswa (Kajian Sosiologi Pendidikan Terhadap Pelanggaran Tata Tertib Siswa Di SMA Negeri 9 Manado. HOLISTIK, 11(21), 1-20.

Tsekeris, C., \& Katrivesis, N. (2008). Reflexivity in sociological theory and social action. Facta universitatis-series: Philosophy, Sociology, Psychology and History, 7(1), 1-12.

Utami, W. (2018). Pengaruh Persepsi Stigma Sosial Dan Dukungan Sosial Terhadap Kesejahteraan Psikologis Pada Narapidana. Journal An-Nafs: Kajian Penelitian Psikologi, 3(2), 183-207. 
Varamitha, S., Akbar, S. N., \& Erlyani, N. (2016). Stigma Sosial pada Keluarga Miskin dari Pasien Gangguan Jiwa. Jurnal Ecopsy, 1(3), 106-115.

\section{About the Authors}

1. Kurniati Abidin, obtained her Doctoral Degree in Sociology from State University of Makassar, Indonesia, in 2016. The author is an Associate Professor at the Department of Islamic Communication and Broadcasting, Faculty of Usuluddin and Dawah, State Islamic Institute of Bone (IAIN), Bone, South Sulawesi, Indonesia. E-Mail: kurniatiarifabidin@gmail.com.

2. Yusuf Djabbar, obtained his Master of Laws from Muslim University of Indonesia (UMI) Makassar, Indonesia, in 2015. The author is an Assistant Professor at the Department of Constitutional Law (Siyasah Syar'iyyah), Faculty of Sharia and Islamic Law, State Islamic Institute of Bone (IAIN), Bone, South Sulawesi, Indonesia. E-Mail: yusufdjabbar@gmail.com. 